\title{
The Application of Buddhist Principles in the Management of Vocational Education Supports the Era of Disruptive Technology
}

\author{
Pogith Tepusa* $^{* 1}$, Soak Bonpo ${ }^{2}$ \\ ${ }^{1}$ Rajamangala University of Technology Thanyaburi \\ ${ }^{2}$ Faculty of Education Maha Chulalongkornrajavittayalai University
}

\begin{abstract}
This research includes objects to study the TVET management framework along with the Buddhist principle. In the Disruptive Technology era to study the TVET management model Buddhist genre in disruptive technology and proposed TVET management model, Buddhist genres of the Disruptive Technology era Focus on presenting the vocational education management model by studying current problems and proposing development patterns and approaches by applying Buddhist principles to benefit the drive of vocational education management using mixed research, quantitative data from a sample of instructors. Under the Office of the Vocational Education Commission, 430 examples of qualitative data from interviews with 13 experts, group discussions, 9 experts. There are two stages of development: 1) Form creation by studying relevant theoretical concepts and research, and information from expert interviews, 2) Examining the model's fidelity with expert evaluation by group discussion, Buddhist TVET management style. Adoption of Buddhist Dhamma principles in the development of learners Instructors in TVET educational institutions are good, especially using the principles of domination, domination, domination for school administrators, which can be used as principles and leadership in the development since the management will determine the direction and policies and provide recommendations on how to promote the leadership of TVET executives in the disruptive technology era.
\end{abstract}

Keywords: TVET, Vocational Education, Buddhist Principle, Disruptive Technology

\section{Introduction}

Continuous scientific and technological knowledge This is combined with advances in new basic scientific fields, such as cognitive science, the function of the brain, and the mind. Relationship between ideas, emotions, and actions, etc. It is essential to create new technologies and innovations that will result in a transform in economic development. "Disruptive Technology" is promising basic technologies in four areas: biotechnology and nanotechnology. Materials Science Technology This will result in the development of 12 new technologies: 1) mobile internet, 2) intelligent programs that can think and work for humans, 3) Internet of Things, 4) Cloud Technology, 5) Advanced Robotics, 6) Unmanned vehicles (Auto).7) Next - Generation Genomics 8) Energy Storage Technology 9) 3D Printing 10) Advanced Materials Technology 11) Advanced Oil and Gas Drilling Technology and 12) Renewable Energy Technology The trend of such technological change affects countries in both socioeconomic dimensions.

Thailand's education system is inconsistent with the labor market. Thailand also encourages people to have bachelor's degrees and study in fields that the labor market does not need, such as communications and publications. In contrast, the industry needs more vocational education workers, thus making graduates inconsistent with the labor market. Thai education must transform into education 4.0, changing the learning and production of people following Thailand.4.0 But educational management cannot get to that point because the methodology and teaching arrangements are just education 1.0 that does not advance to level 3.0. This leads to innovative products, producing people who will be self employed and modern entrepreneurs with the skills to make a living on their own, Kiatanan (1996) said that vocational education management could meet the needs of Thai education in the 4.0 era because vocational education management is the development of human resources, focusing on producing workforce in different fields, meeting the professionallines that the labor market needs, to promote and improve the competitiveness of the country. By encouraging students to have creative qualities. Critical thinking, professional skills, life skills, knowing team work is to be able to collaborate happily with others, from the past to the present.

They are developing a form of educational management or training to enhance the skills needed to work. The process terminations are used differently by region and the scope of the content of studies or training. For example, apprenticeship, industrial arts, technical education, technical/ vocational education, occupational education.

The problems to be known in this research are as follows: 1) The approach to TVET teaching courses that are connected and in line with the Thailand Driving Action Plan and the 20 - Year National Strategy (2017 - 2036), 2) Guidelines for the management and implementation of technology and innovation in learning. The transfer of knowledge and leverage of the knowledge and wisdom we have accumulated to innovate and manage gives everyone unlimited access to existing knowledge. Anytime, anywhere. Thoroughly, equally. At all ages, to be an important force in supporting the country's sustainable development and development 3) Providing operational operations. It requires leadership because there is no system of forced follow - up to the lead. What principles do TVET executives use to 
dominate, dominate and dominate jobs to make TVET management a success?

\section{Literature Review}

\subsection{Definition of Disruptive Technologies}

Disruptive technology refers to innovations or technologies that are used to create markets and value products that are used by nasty products and have a severe impact (Disrupt) impact on the market of existing products, as well as potentially causing businesses that use traditional technologies to be knocked down or closed, unlike conventional innovations that Nama uses for efficiency enhancing purposes. Increase product quality or reduce traditional route costs only. The process by which new technologies "disrupt" old technologies is not something new but has been going on from the past continuously.

\subsection{Impact of Disruptive Technology}

Christensen, C. M. and Raynor, M. E. (2003) classify technology into two categories: sustaining technologies, technology focused on improving the efficiency of products in conventional mechanical systems. The other type of technology is called Disruptive technologies, which develop products/services to have new systems and new looks cheaper. Disruptive technology may or may not be the latest technology. However, there are changes in specific market elements, such as quality, production process efficiency, cost or price, which makes these technologies the right conditions desirable to become popular with the process market where new technologies change system. (disruptive) Old technology is not new, the impact of disruptive technology, the labor market.

"Machines are coming to take our jobs, " the statement is widely debated. Many research agencies predict the trend towards modern technology, both automation. AI IoT (Internet of Things) robots are widely used in the production of goods, services, and everyday life, whether to replace or even take over the labor market. The OECD (2018) estimates that over the next 15 years, $14 \%$ of workers are at high risk of being replaced by automation, and $30 \%$ face significant changes in skills used in work, and a recent Mckinsey Global Institute report in February 2019 estimated that about half of work activities used by people would be replaced by automation. In addition, many countries worldwide have experienced the difficulty of not being able to create young people and working - class people with work skills and life skills high enough to face disruptive technology, raising the question of Thailand's labor and education and training market. Ready to cope with the changes in job conditions and workforce skills of the future?

\subsection{Improving labor skills: Thailand ready to deal with disruptive technology waves}

Technological advances contribute to new businesses and careers. Future workers need a "new set of skills" that can work with robotics and automation, especially technology and digital skills. This puts pressure on workers to develop new skills at all times if they want to stay in the labor market, in line with the World Economic Forum's "The Future of Jobs Report 2018", which surveys entrepreneurs around the world on the need to improve their skills by 2022. According to the report, entrepreneurs give consistent opinions to the global picture. In other words, about half of Thai workers have to develop skills in both "Technical Skill", especially analytical thinking and innovative thinking, creative thinking and initiatives, and "Human skill" that can understand the minds and emotions of others. Robots cannot learn these things. Thailand's skill development mechanisms and institutes are available in both the public and private sectors under the Skill Development Promotion Act B. E.2545 (2002). Bangkok's vocational training centers train 20, 000 workers a year. In addition, specialized training institutions such as electrical and electronic institutions and educational institutions that provide training services to the general public, in 2018, the Ministry of Labour developed the potential of workers in the workplace.4.78 million students and citizens Private Sector Large businesses often have institutions that provide training for their employees, such as THE SCG's Taksapipat School, Panyapiwat Company of CP All, Michelin Thailand, etc.

\subsection{Concepts of Vocational Education Educational \& Training Techniques (TVET)}

The relevant concepts and theories in this section include 1) meaning, vocational education, educational techniques and training (TVET), and 2) the skills required for TVET in the 21 century as follows: Technical Vocational Education and Training (TVET) is recognized worldwide for its role in preparing people to participate in creating work value and skilled sources of the workforce. According to a 2001 joint publication by the United Nations Educational, Scientific and Cultural Organization (UNESCO) and the International Labour Organization (ILO) on Vocational Education and Technical Studies and Training for the 21 Century, TVET is defined as 1) as an essential component of the ordinary line, 2) prepares people into the profession and the world of work effectively. Uwameiye\& Uddin, 2017). Similarly, UNESCO (2009) defines TVET as public and private educational institutions in many forms. Formal or informal education is intended to provide all community members with access to this learning path throughout their lives.

From the above definition, TVET aims to eliminate ignorance. Increase knowledge, develop skills, and cultivate the attitudes necessary to enter the profession and advance (Kukoyi, 2009), in line with the concept of Instrumental Sornil and faculty (2005), explaining that TVET's goal is to develop people to their full potential. With the environment in mind, Empower people for sustainable development, provide lifelong education, have professional qualifications, manage open and flexible learning. Certified and compared to transfer experience, high priority to vocational education by designating it as a national agenda. Investment reforms have been implemented in line with the development plan. There are benchmarks for indicators in quality management, and there is a link between different studies. Continuing education and work Use performance - based learning with the core skills, skills needed for lifestyle. Personnel must have the right qualifications, quality, and qualifications, with continuous improvements for the status of graduates and 
professional workers to be comparable to other professional fields.

\subsection{Management of education according to Buddhist principles}

Buddhism means the principles or teachings of Buddhism that Buddha has laid out. There are many aspects of Buddhist doctrine, including those related to their conduct, in the field of living with others, and in domination. Treatment of parents in the field of occupation Social co op, helping others, etc. (PatcharalaiSangsorn, 2018) Educational management refers to the processes or educational activities that the persons involved have collaborated on, using administrative resources to develop human resources to be good members of society for the intended purpose.

Buddhist methods for education executives to manage themselves, People, management, and management of education executives can apply Buddhist methods or guidelines to the management of all three areas: self administration. Human management and management are as follows:

Self - Administration by The Book of P. S. Pyutto (2003) discussed the adoption of Buddhist principles in the management of education executives who have to work with many people, saying that working happily with both himself and his colleagues has a positive effect on the quality of education, so education executives must be knowledgeable and virtuous to be used in their governance. Very patronaged dharma (consciousness) The Earth - Protected Dhamma (HiriOttappa), Ariyasaj 4, Sacrament 5, Kalyanmit 7 and Sappuristham 7, which is highly important in holding themselves in society in a peaceful manner, in line with ThepVisutmethee (Panya Nandapikku, 2003), discussed the characteristics of good people in Buddhism. It must consist of 7 principles (Spurisdham 7), namely to be a reason acquaintance, know the consequences, know about them, know the community, and be an acquaintance of individuals.

The management of people and the adoption of Buddhist methods is to adopt buddhist principles to improve people, develop people, and be a tool to direct the work of people in the organization. PhraDhammapidak (Ph. D.) Pyutto) discussed the qualifications for the management of people in the book "Buddhist Dhamma" in the topic of Dharma on Sangha 4: the principle of relief to hold people's hearts and harmonize society in harmony, which is a principle for expressing kindness among the ordinary people, with four principles: eating (allowance, sharing), piyavaja (loving speech), attentiveness (benefiting him), and Samanatta (making himself compatible with him does not hold his own, joining in suffering), in line with Bantheng Papijit (2005), discusses four fair principles for use as administrative bases: wisdom (the power of wisdom), viriyapal (force of perseverance), Anawatphala (force of good faith) and sangha (force of unity).

Administration means promoting workers to work at their best or to their potential. School administrators deserve to apply moral principles in the administration, which will affect the learner and help promote the quality of the learner. Be honest, diligent, patient. Disciplined, able to live with others.

\section{Research Methods}

This research Mixed methods research is used by quantitative research and qualitative research. An essential characteristic of qualitative research is qualitative data collection, including feelings. Opinions, beliefs, values, and attitudes of individuals regarding the management of Buddhist TVET In the Disruptive Technology era, data collection methods are in - depth interviews and focus groups, analyzing data with interpretation analysis. This process involves finding ideas that can be used to describe and explain them to obtain more reliable and weighty information.

Population and samples A group of informants in quantitative research is called a sample, qualitative research section, a group of targeted informants. Seung has the following details in selecting a group of informants: Quantitative research, the population used in this study includes vocational education personnel who teach. Under the Office of the Vocational Education Commission

Table 1: Shows the number of vocational education personnel teaching. Under the Office of the Vocational Education Commission Semester 1 Academic Year 2016

\begin{tabular}{|c|c|c|c|c|}
\hline Teacher & Tutor & $\begin{array}{c}\text { Teacher } \\
\text { Assistant }\end{array}$ & $\begin{array}{c}\text { Government } \\
\text { Employees (Teachers) }\end{array}$ & Combine \\
\hline 14,873 & 10,236 & 1,386 & 4,024 & 30,519 \\
\hline
\end{tabular}

Source: Information Technology Group for Vocational Education Management

Samples used in this research The researchers determined a sample from the vocational education personnel who were teaching. Under the Office of the Vocational Education Commission Semester 1, 2016: 30, 519 students, calculated according to Taro Yamane (1967) formula by calculating a sample of 395 people, which is a minimum sample, to make the resulting data more reliable, the sample is set to 430 using purposive sampling.

The key informants of in - depth interviews are 13 academics, executives, TVET educational institutions, key informants of focus group discussions, 9 qualified persons regarding TVET education management and Buddhist education management.

\section{Discussions}

Research on" The application of Buddhist principles to be used in TVET management supports the DisruptiveTechnologyera. "The researchers collected data using questionnaires, interviews with quantitative research samples, and qualitative research samples to analyze the data. The researchers conducted analytically and presented in episodes to answer the objectives of the research as follows: 
Table 2: Number and Percentage of Respondent General Data $(\mathrm{N}=430)$

\begin{tabular}{|l|c|c|}
\hline Personal Factors & Amount & Percent \\
\hline Sex & & \\
\hline Male & 207 & 48.1 \\
\hline Female & 223 & 51.9 \\
\hline Age & & \\
\hline $21-30$ years & 84 & 19.5 \\
\hline $31-40$ years & 127 & 29.5 \\
\hline $41-50$ years & 129 & 30.0 \\
\hline $51-60$ years & 84 & 19.5 \\
\hline 61 years and above & 6 & 1.4 \\
\hline Work Experience & & \\
\hline $1-5$ years & 111 & 25.8 \\
\hline $6-10$ years & 82 & 19.1 \\
\hline $11-20$ years & 124 & 28.8 \\
\hline 21 years or more & 113 & 26.3 \\
\hline Highest education level & & \\
\hline Bachelor's Degree & 270 & 62.8 \\
\hline Master & 146 & 34.0 \\
\hline Doctorate & 9 & 2.1 \\
\hline Others & 5 & 1.2 \\
\hline Affiliated with The Discipline & & \\
\hline Rail Transport Branch & 8 & 1.9 \\
\hline Macatronics and Robotics Branch & 14 & 3.3 \\
\hline Aircraft Mechanic Branch & 4 & 0.9 \\
\hline Industrial Robots & 1 & 0.2 \\
\hline Logistics & 16 & 3.7 \\
\hline Modern Agriculture, Agriculture & 111 & 25.8 \\
\hline General Disciplines Basics & 81 & 18.8 \\
\hline $\begin{array}{l}\text { Other professions } \text { (Mechanic, } \\
\text { Information, Business, etc.) }\end{array}$ & 195 & 45.3 \\
\hline & & \\
\hline
\end{tabular}

Affiliated with The Discipline The majority of respondents were affiliated with other professions (information technicians, businesses, etc.), $45 \%$ of whom were $45 \%$ ofthem, 3 of whom were affiliated with modern agriculture, agriculture, 111 persons, 25 percent.

The results of the analysis of the application data of Buddhist Dhamma principles in the management of school administrators following the principles of domination. Domination and dominance
Table 3: Average and Standard Deviation Application of Buddhist principles in the management of school

administrators following the principle of domination according to the expectations/perceptions of the instructor $(\mathrm{N}=430)$

\begin{tabular}{|c|c|c|c|c|c|c|}
\hline \multicolumn{2}{|c|}{ Domination } & \multirow{2}{*}{\begin{tabular}{|l|} 
Mean \\
4.18 \\
\end{tabular}} & \multicolumn{2}{|c|}{ SD translate } & \multirow{2}{*}{\begin{tabular}{|c|}
$\mathrm{t}$ \\
9.270 \\
\end{tabular}} & \multirow{2}{*}{$\begin{array}{c}\text { Sig. } \\
0.000\end{array}$} \\
\hline 1) Have an & expect & & 0.79 & very & & \\
\hline $\begin{array}{l}\text { the principles of } \\
\text { school } \\
\text { management }\end{array}$ & perceive & 3.85 & 0.79 & very & & \\
\hline \multirow{2}{*}{$\begin{array}{l}\text { 2) Clearly set goals } \\
\text { for the } \\
\text { administration of } \\
\text { the school. }\end{array}$} & expect & 4.17 & 0.81 & very & 6.855 & 0.000 \\
\hline & perceive & 3.88 & 0.79 & very & & \\
\hline \multirow[b]{2}{*}{$\begin{array}{l}\text { 3) Operate in } \\
\text { accordance with } \\
\text { the goals of the } \\
\text { school and } \\
\text { conform to their } \\
\text { own unique } \\
\text { abilities. }\end{array}$} & expect & 4.17 & 0.74 & very & 7.249 & 0.000 \\
\hline & perceive & 3.88 & 0.77 & very & & \\
\hline \multirow{2}{*}{$\begin{array}{l}\text { 4) Manage to suit } \\
\text { existing budgets } \\
\text { and resources }\end{array}$} & expect & 4.21 & 0.76 & very & 9.241 & 0.000 \\
\hline & perceive & 3.81 & 0.84 & very & & \\
\hline \multirow{2}{*}{$\begin{array}{l}\text { 5) The timing of } \\
\text { school activities is } \\
\text { allocated } \\
\text { appropriately. }\end{array}$} & expect & 4.19 & 0.76 & very & 7.371 & 0.000 \\
\hline & perceive & 3.87 & 0.81 & very & & \\
\hline \multirow{2}{*}{$\begin{array}{l}\text { Overview of } \\
\text { Domination }\end{array}$} & expect & 4.18 & 0.65 & very & 9.990 & 0.000 \\
\hline & perceive & 3.86 & 0.68 & & & \\
\hline
\end{tabular}

The instructors recognized the application of Buddhist principles in the management of the school administrators according to the principles of domination, overall at a very high level (3.86) when considering eachother, there was a high level of awareness among the most common, including " clearly targeting the management of the school " (3.88) and " operating in accordance with the goals of the school and conforming to their unique abilities " (3.88).

Instructors have expectations. The application of Buddhist principles in the management of school administrators according to the principle of domination as a whole is very high (4.18). When considering eachother, there are many expectations in place, with the most average expectations such as "managed to suit the budget and resources available" (4.21)

Comparison results in Perception/Expectations Application of Buddhist principles in the management of school administrators in accordance with the principles of domination. Overall, it found that there is a statistically significant difference at the level of $0.05(\mathrm{t}=9.990$, Sig. $=$ 0.000) considering the comparison results. Perception/expectations on a case - by - case basis showed a statistically significant difference at level 0. 
Table 4: Average and Standard Deviation Application of Buddhist principles in the management of school administrators according to the principle of domination according to the expectations/perceptions of the instructor $(\mathrm{N}=430)$

\begin{tabular}{|c|c|c|c|c|c|c|}
\hline \multicolumn{2}{|l|}{ Dominating people } & Mean & SD & translate & $\mathrm{t}$ & Sig. \\
\hline \multirow{2}{*}{$\begin{array}{l}\text { 1. Have suggested development for personnel by providing } \\
\text { back - to - back information after teaching instruction. }\end{array}$} & expect & 4.17 & 0.74 & very & \multirow{2}{*}{9.234} & \multirow{2}{*}{0.000} \\
\hline & perceive & 3.81 & 0.80 & very & & \\
\hline \multirow{2}{*}{$\begin{array}{l}\text { 2. Guide and compliment colleagues creatively in a friendly } \\
\text { tone }\end{array}$} & expect & 4.25 & 0.76 & very & \multirow{2}{*}{9.134} & \multirow{2}{*}{0.000} \\
\hline & perceive & 3.90 & 0.82 & very & & \\
\hline \multirow{2}{*}{$\begin{array}{l}\text { 3. Pay attention to the staff by assigning the work } \\
\text { accordingly to make the most of both the learner and the } \\
\text { school. }\end{array}$} & expect & 4.25 & 0.78 & very & \multirow[b]{2}{*}{8.172} & \multirow[b]{2}{*}{0.000} \\
\hline & perceive & 3.92 & 0.78 & very & & \\
\hline \multirow{2}{*}{$\begin{array}{l}\text { 4Realize their roles and duties as executives with the aim of } \\
\text { working in the best interests of the learner. Teachers \& } \\
\text { Communities }\end{array}$} & expect & 4.27 & 0.78 & very & \multirow[b]{2}{*}{8.133} & \multirow[b]{2}{*}{0.000} \\
\hline & perceive & 3.95 & 0.79 & very & & \\
\hline \multirow{2}{*}{$\begin{array}{l}\text { 5. Always allow teachers and school board members to } \\
\text { participate in comments. }\end{array}$} & expect & 4.27 & 0.82 & very & \multirow{2}{*}{8.094} & \multirow{2}{*}{0.000} \\
\hline & perceive & 3.94 & 0.87 & very & & \\
\hline \multirow{2}{*}{ Overview: Domination } & expect & 4.24 & 0.68 & very & \multirow{2}{*}{10.553} & \multirow{2}{*}{0.000} \\
\hline & perceive & 3.91 & 0.70 & very & & \\
\hline
\end{tabular}

from table 4 see Instructors are perceptive. Application of Buddhist Dhamma principles in the management of school administrators in accordance with the principles of domination people, overall, are very high (3.91). On a case by - case basis, there was a high level of awareness in all of them, with the most perception averages: "Recognize their roles and duties as executives to work in the best interests of the learner. Teachers \& Communities" (3.95)

Instructors have expectations. The application of Buddhist principles in the management of school administrators according to the principles of domination as a whole is very high (4.24) Considering that there are many expectations in all ofthem, with the most average expectations being " recognizing their roles and duties as executives to work in the best interests of the learner. Teachers and communities " (4.27) " Always allow teacher personnel and school board members to participate in comments" (4.27)

Comparison results in Perception/Expectations The application of Buddhist principles in the management of school administrators following the principles of domination of people were found to be overall. There is a statistically significant difference at the level of $0.05(\mathrm{t}=10.553$, Sig. $=$ 0.000) considering the comparison results. Perception/expectations on a case - by - case basis showed a statistically significant difference at level 0 .

Table 5: Average and Standard Deviation Application of Buddhist principles in the management of school administrators according to the principle of domination according to the expectations/perceptions of the instructor $(\mathrm{N}=430)$

\begin{tabular}{|c|c|c|c|c|c|c|c|}
\hline \multicolumn{3}{|c|}{ Domination } & Mean & SD & translate & $\mathrm{t}$ & Sig. \\
\hline \multirow{2}{*}{\multicolumn{2}{|c|}{ 1) Love and enjoy working on management within the school. }} & expect & 4.33 & 0.77 & very & 8.574 & 0.000 \\
\hline & & perceive & 4.02 & 0.80 & very & & \\
\hline \multirow{2}{*}{\multicolumn{2}{|c|}{ 2) Diligent thinking and innovating for schools }} & expect & 4.34 & 0.74 & very & 9.050 & 0.000 \\
\hline & & perceive & 4.01 & 0.78 & very & & \\
\hline \multirow{2}{*}{\multicolumn{2}{|c|}{ 3) Constantly think and plan work to ensure efficient operation. }} & expect & 4.32 & 0.72 & very & 8.793 & 0.000 \\
\hline & & perceive & 4.00 & 0.76 & very & & \\
\hline & \multirow{2}{*}{$\begin{array}{l}\text { Pay attention to decisions under the resolutions of the meeting } \\
\text { approved by the majority of personnel. }\end{array}$} & expect & 4.25 & 0.82 & very & 6.568 & 0.000 \\
\hline & & perceive & 3.99 & 0.82 & very & & \\
\hline & \multirow{2}{*}{$\begin{array}{l}\text { Errors caused by performing various duties will be investigated } \\
\text { and considered together to find out. Solutions, stay updated }\end{array}$} & expect & 4.24 & 0.83 & very & 8.407 & 0.000 \\
\hline & & perceive & 3.90 & 0.86 & very & & \\
\hline & \multirow{2}{*}{ Overview: Domination } & expect & 4.30 & 0.68 & very & 10.187 & 0.000 \\
\hline & & perceive & 3.98 & 0.70 & very & & \\
\hline
\end{tabular}

From Table 5, the instructors were perceived to apply Buddhist principles in the management of school administrators according to the principle of dominating people overall at a very high level (3.98) considering that there was a high level of awareness in all ofthem, with the most perceptive averages including " 1 Love and happiness working on management within the school " (4.02)

Instructors have expectations. The application of Buddhist principles in the management of school administrators according to the principle of domination of the work overall is very high (4.30). When considering eachother, there are all the high expectations, with the most average expectations: "2 Diligent thinking and innovating for the school" (4.34)
Comparison results in Perception/Expectations The application of Buddhist principles in the management of school administrators by the principles of domination of the work was found. There is a statistically significant difference at the level of $0.05(\mathrm{t}=10.187$, Sig. $=0.000)$ considering the comparison results. Perception/expectations on a case - by - case basis showed a statistically significant difference at level 0 .

Respondents' general data analysis results inThe respondents were male and female. A similar number were 223 females, 51percent.129 people have work experience between 11 and 20 years, 124 are 28 percent.

The results of the analysis of the application data of Buddhist Dhamma principles in the management of school 
administrators in accordance with the principles of domination. Domination and dominance

1) Instructor awareness and expectations towards the Application of Buddhist principles in the management of school administrators in accordance with the principles of domination. The perception by the image is very included. There was a high level of awareness in all of them on a case - by - case basis, with the most perception averages. Two are "clearly targeted in the school's management" and "operate by the school's goals and in line with their unique abilities. "Visual expectations are included to a considerable extent. It was found to be at a very high level on a case - by - case basis, with the most average expectations being "managed to fit the budget and resources available. " Comparison results Perception/Expectations It found that overall, There was a statistically significant difference at level 0.05 , considering the results of the comparison individually, there was a statistically significant difference at 0 .

2) Instructor awareness/expectations towards the Application of Buddhist Dhamma principles in the management of school administrators according to the principles of domination of people. The overall perception is very high. On a case - by - case basis, it was found that at all levels, the most perceptive averages include "recognizing their roles and duties as executives to work in the best interests of the learner. Teachers and communities" overall expectations are very high. It was found to be at a very high level of all on a case - by - case basis, with the one that averaged the most expectations. Two are "aware of their roles and duties as executives to work in the best interests of the learner. And "always allow teachers and school board members to participate in comments. " Perception/Expectation Comparison Results: Overall, There was a statistically significant difference at level 0.05 , considering the results of the comparison individually, there was a statistically significant difference at 0 .

3) Instructor awareness/expectations towards the Application of Buddhist principles in the management of school administrators according to the principle of domination overall perception is very high. On a case by - case basis, there was a high level of awareness, with the most perceptive averages: "Love and happiness working on management within the school. "Overall expectations are very high. Considering each other, there was a high level of awareness, with the one that averaged the most expectations, including "diligent thinking and innovating for the school. " Overall recognition/expectations There was a statistically significant difference at level 0.05. Considering the results of the individual comparison, there was a statistically significant difference at level 0.05 .

\section{Conclusion and Sugession}

\subsection{Conclusion}

Buddhist TVET management style In theDisruptive Technologyera. Based on document analysis, quantitative analysis, and qualitative analysis, it is concluded that digital transformation has been created in the disruptive technology era. Leads to changes in skills needed for work and life.
TVET institutions must make the most of integration, combining new technologies to prepare learners for the world of work today and in the future. Managing TVET to be ready for change under disruption flow Executives can adopt Buddhist principles for holistic organizational management. If the organization has the knowledge and, in conjunction with promoting morality for its members, it will lead the way to sustainable changes in society and the environment and elevate it to digital organizations.

In research on the Buddhist TVET management style in the Disruptive Technology era, to guide the agencies involved in the development of Thai people in the 4.0 era to produce graduates to the labor market and train to increase skills for workers in the labor market. By managing education and training in technology and vocational education. (technical and vocational education and training: TVET) according to Buddhist management principles. In the Disruptive Technology era, researchers analyzed and defined patterns with system theory as follows:

1) The concept of Buddhist management, the domination of people, dominates the work. Education Executive TVET Apply Buddhist management principles, dominate, dominate, dominate jobs.

2) Executives apply Buddhist management to dominate, dominate the work as a whole at a very high level. Considering the case, it was found to be very high.

\subsection{Suggestion}

1) Recommendations for applying Buddhist principles in the performance of executives, including "Focus on friendly management, reduce bias, please him to pay attention to us, proclamation, use polite verbality, to provide justice to subordinates".

2) Recommendations for managing learning skills and innovation for students include "Providing equipment and tools that will support skills reinforcement and provide adequate access to innovation for current events. Provide stable information and internet system in use. Promote continuous learning of innovation and in line with current conditions. They are providing budgets to promote innovation".

3) Recommendations for applying Buddhist principles in the management's performance include "emphasis on friendly management, reducing bias, taking his heart to care about us, relying on, verbally using polite words to provide justice to subordinates. "

\section{Acknowledgement}

The author would like to thank all informants and qualified persons interviewed for information and participants who have contributed to the coordination of information and compiled this article.

\section{References}

[1] Asian Productivity Organisation (APO) (2018), APO Productivity. Data book.

[2] Christensen, C. M., \& Raynor, M. E. (2003). The Innovator's Solution: Creating and Sustaining Successful Growth. Harvard Business Review Press. 
[3] Clifton, Jim. (๒๐๐๖). Universities: Disruption is Coming. http: //news. gallup. com/opinion/chairman/๑๙のอ๓๓/universitiesdisruptio $\mathrm{n}$ - coming. aspx

[4] Edward M. Reeve.21st century skills needed by students in technical and vocational education and training (TVET). Asian International Journal of Social Sciences, 16 (4), 54 - 61. doi: 10.29139/aijss.20160404

[5] J, Chui, M, Bughin, J, Dobbs, R, Bisson, P \& Marrs, A (2013), Disruptive technologies: advances that will transform life. Business, and the global economy, vol.12, McKinsey Global Institute San Francisco, CA.

[6] Manyika, J, Chui, M, Bughin, J, Dobbs, R, Bisson, P \& Marrs, A (2013), Disruptive technologies: advances that will transform life. Business, and the global economy, vol.12, McKinsey Global Institute San Francisco, CA.

[7] OECD (2018). Transformative Technologies and Jobs of the Future. Background Report for the Canadian G7 Innovation Ministers' Meeting, Montreal, Canada, 27-28 March 2018.

[8] Raihan, A., \& Han, S. L. (2011). Gateways Lifelong Learning in TVET for a Viable Future of Bangladesh. Journal of Lifelong Learning Society, 72), 119 - 136. doi: 10.26857/jlls.2011.08.7.2.119

[9] Ramlee Mustapha (2016) Green and Sustainable Development for TVET in Asia. [on line]. Available: https: //www.researchgate. net/publication/316563359_Green_and_Sustainable_D evelopment_for_TVET_in_Asia

[10] Reeve, E. M. (2016).21st century skills needed by students in technical and vocational education and training (TVET). Asian International Journal of Social Sciences, 16 (4), 54 - 61. doi: 10.29139/aijss.20160404

[11] Tercia Elaine Terblanche. (2017). TVET Colleges in South Africa: A Framework for Curriculum change. Stellenbosch University [on line]. Available: https: //scholar. sun. ac. za.

[12] UNESCO Bangkok (2011). Higher education and technical and vocational education and training. Retrieved from http: //tinyurl. com/mwj8dnl http: //www.unescobkk.

org/education/resources/resources/education-systemprofiles/thailand/higher-tvet/

[13] Valentine, E. (2013). ICT in vocational education and training: a view of information and communication technology in vocational education in New Zealand. doi: 10.13140/RG.2.2.25639.34725

[14] Willer, D. (๑๙๘๖). Scientific sociology: Theory and method. Englewood cliffs, New Jersey: Prentice-Hall.

[15] World Bank (2016). World Development Report 2016: Digital Dividends, Washington, DC: World Bank 